\title{
The Paradox of Tourism in Underdeveloped Economies
}

\author{
Gina Ferrara \\ (Department of Economics, Shanghai University, China)
}

\begin{abstract}
Tourism plays a major role for many countries' economies; however, for countries with developing economies, the challenge is simply establishing a tourism industry. In order to have a prosperous tourism industry, investment, stability, and infrastructure are key. The paradox lies in the fact that financial capital is necessary to grow tourism, and in an economy where funding is scarce, the ability to grow is limited.
\end{abstract}

Keywords : developing country, economic growth, tourism, travel, underdeveloped economy

\section{Introduction}

It can be difficult to develop a tourism industry in a county which is still developing economically; therefore leading to a low demand for tourism and surprising the few tourists with unexpectedly high costs. As a county's economy develops and it becomes more financially stable, it can increase its ability to host tourists; thus establishing a tourism industry. A major challenge for a developing country lies in the process of establishing a tourism infrastructure. Every country has unique characteristics that may lure tourists to come visit; however, some destinations are much easier to travel to than others, not only geographically. The ease of finding accommodation, transportation, tours, and activities is a major factor for a country to increase the number of tourists that visit each year. Tourism can have a positive effect on a county's economy and can produce jobs in the service industry for middle class workers; therefore it is highly beneficial for a developing nations to grow tourism. The paradox lies in the fact that money is necessary to grow tourism and no money means limited growth.

\section{Challenges of tourism development}

A tourist industry can help strengthen stability in developing countries, but countries must first overcome the challenges of building up a tourism infrastructure. Although tourism can often promote peace, a country must first possess a peaceful environment in order for peace to flourish. [1] For some developing countries this can be more difficult to overcome than others.

Investments in infrastructure is the foundation to building up a tourism industry in counties with developing economies. Less developed countries must strategically coordinate their efforts to find capital investment to build necessities such as airports, hotels, roads, and tourist attractions if they want to bring in a high volume of visitors. In addition to physical infrastructure, investments in human capital must be made as well. For example, working in the international hospitality industry requires special training. International standards are also higher, so the quality of hospitality staff such as hotels, restaurants, and drivers may need to be improved to meet these higher expectations. When working with foreign tourists, it is also necessary to be aware of different cultures and practice cultural sensitivity, another skill which requires investment in training. It is all important for a country to create an implementation plan and budget accordingly. In order to create a stable and safe environment for tourism, it is up to the government to collaborate with local communities and international stakeholders. Although, the country leaders play a critical role in creating this stable infrastructure for tourism, it is essential to receive contributions from internationals stakeholders as well. For example, international tour operators can hold a major function in this process by making an effort to assist developing countries with financial investments, tourism knowledge and technology. [2] Since tourism is still a work in progress for many countries with developing economies, foreign investment in tourism, such as international tour operators, is critical to their growth.

Investment in infrastructure allows a country to develop well-trained personnel, tour guides, roads, airports, visitor centers, and adequate accommodation - basic necessities for the tourism industry to prosper. Since developing economies may not have the financial means to start up a company, it is often necessary for foreign tour companies to create a presence or partner with locals in the country for a tour industry to thrive. Although, it is possible for locals to start very small tour companies without the help of international companies, it may be difficult to advertise to tourists abroad. Many tourist like to book tours before arriving in a country, especially developing nations which are still building a tourism infrastructure. In addition to the necessity of tours and guides, comfortable and affordable accommodation options is an important factor for tourists when booking a destination. Countries who do not yet have a developed tourism infrastructure tend to have limited accommodation available to tourists, and sometimes even more limited for foreign tourists. Some countries 
domestic hotels/guest houses are not permitted to even host foreign tourists. Usually after a tourism infrastructure is established, foreign hotel chains will enter the county and build hotels for foreign visitors. This addition of foreign hotels has pro and cons for the developing country. On the plus side, it offers more options for tourist accommodation, and may be more attractive to foreign visitors who are hesitant to visit a developing nation; in addition, these hotels can provide jobs for the local community. The downside is that the foreign hotel brands will repatriate the profits, which does not benefit the domestic economy. Unlike foreign hotels, domestic hotels/guest houses allow revenue to remain in the domestic economy; however, the international advertising and employment opportunities from foreign hotels are a benefit for the developing nation's economy. When a country has a stable tourism infrastructure including, accommodation, trained personnel, reputable tours, experienced guides, international recognition, and a safe environment, the tourism industry can flourish and the number of tourists each year will grow. As a destination becomes more popular, its tourism industry expands, which in turn has a positive effect on the economy. [3]

The laws, regulations and safety of a countries with developing economies is an important factor for building a tourism infrastructure; in addition, ensuring the conditions are met is a challenge for countries with a large presence of corruption and crime. In regards to the safety of a country for tourists, a country must have and enforce laws and regulations which protect the people. This includes factors such as a presence of active law enforcement personnel for the safety of the community and tourists. One problem that may deter tourists in countries with developing economies is the presence of corruption among government officials and law enforcement. For example, a large presence of law enforcement personnel does not make a tourist feel safe if they are known for being corrupt or extorting tourists for petty offenses. In addition to reducing or better yet, eliminate corruption, developing countries must also reduce crime to create a safe environment for tourists. Countries with high crime rates, creates a safety risk for foreign visitors; thus reducing the number of tourists willing to visit that country.

\section{Tourism in developing economies}

Every nation has something that can attract a tourist to visit it, but if the tourism infrastructure of that country is unstable, it may be very difficult for a tourist to visit. For example, Nigeria has the potential to be a very attractive tourist destination, but it faces a number of stability problems. Nigeria has failed to establish a tourist industry due to being confronted with societal problems such as poverty, corruptions, and a lack of infrastructure. The country is currently stuck in an unfortunate situation where it has the potential to promote peace and development through tourism, but tourism can only be present in areas where peace and development already exist. [4]

Some countries with developing economies actually rely on tourism as the basis of their economy. Jamaica is an example of a country that now depends on the tourism industry to keep its economy functioning. When Jamaica gained its independence, it was reluctantly forced to collaborate with the International Monetary Fund (IMF) and World Bank due the large amount of debt it owes. Upon its entrance, foreign companies began to take advantage of Jamaica's situation by exporting enormous amounts of foreign food products to Jamaica including fruits, vegetables and dairy products. Because these products were able to be sold in Jamaica at such low prices, they slowly destroyed the country's local farming and dairy industry; thus reducing the amount of exports for Jamaica and hurting its domestic economy. Since Jamaica could no longer rely on agriculture and exports to grow its economy, tourism became the primary focus of the country. Since tourism is so important to Jamaica, the country invests much of its capital in the industry. [5] Each year Jamaica's tourism industry grows and the infrastructure becomes more stable; thus more hotels are built, more staff are hired, and new roads are built. Although Jamaica's tourism industry is thriving, it remains a country in severe poverty and its economy still struggles with debt.

If a country wishes to grow its tourism industry, strategic planning in necessary to build a tourism infrastructure that will meet the demand of visitors and keep prices relative. Myanmar has recently had a large influx in foreign visitors; however, the country is beginning to gain a reputation as a bad value for money according to Myanmar Times. [6] Although some may say Myanmar is an inexpensive country to travel, its prices are comparatively higher than its neighboring South East Asia countries. Since Myanmar is still developing its tourism infrastructure, the costs of hotels and flights within the country are priced much higher than that of its neighbors with more established infrastructures, such as Thailand. Thailand attracts visitors with famous cites, beach towns and landmarks such as Bangkok, Phuket and "James Bond Island." In addition, Cambodia has the infamous Angkor Watt temples, India has the Taj Mahal and Malaysia's Kuala Lumpur is a well-known international destination. Although Myanmar has a number of amazing tourist destinations, it is still working to becoming more appealing to increase foreign visitors. Currently leaders of Myanmar are working diligently to develop new brand strategies to increase tourism such as rebranding the term "low season" to green season, inviting international film makers to shoot scenes in the nation's key destinations, and creating unique new festivals. According to Zayar Myo Aung, a director at the tourism ministry, "we must reduce dependence 
on seasonality. We need to make sure to let the world know that Myanmar is a year-round destination. It will reduce all the costs." Kaung Min Khant, assistant secretary of Myanmar Tourism Marketing, says "we need to change visitors' perception that Myanmar is expensive and only a land of pagodas. To reduce costs, we need more visitors. If our hotels enjoy full occupancy rate and airlines enjoy satisfactory capacity, we will not be expensive anymore." [7] Myanmar's tourism leaders hope these new additions to the infrastructure and change of brand image will grow tourism and reduce costs for tourists.

\section{Economic effect}

Tourism is one of the strongest drivers of world trade and prosperity, but it has the potential to have both positive and negative effects on a country. Some countries depend on tourism completely to support the economy, some appreciate it as a positive influence on the economy, and other desire to have a prosperous tourism industry to grow their economy. As previously mentioned, building the infrastructure for tourism with a developing economy is a challenge; however, if done successfully, a booming tourism industry does have the potential to alleviate poverty. [8]

Tourism can have a very positive effect on a developing economy, especially if an effective infrastructure is put in place. One of the most significant effects on the economy is the jobs created by tourism. With the development of a tourism industry comes an increased demand in hospitality staff such as hotel staff, drivers etc. Indirect employment is also impacted in areas such as retail and local transportation. Tour operators often make shopping stops and hotels may provide free shuttles to shopping areas to assist retailers and encourage spending in the host country. Additionally, as more people in a developing economy become employed, then more people have money to spend. This influx in employment and spending on goods and services can develop into the "multiplier effect;" thus creating more jobs for the area. In addition to the big businesses and government opportunities in the tourism industry, small businesses also have an opportunity to get involved by selling local goods or providing tours; thus benefiting the rural communities as well. A growing tourism industry can also generate extra tax revenues in country through airport and hotel taxes. If corruption is minimal, then taxes earned by the government can be used to improve country facilities such as hospitals, housing, and schools. [9]

Although the positive effects of tourism appear to benefit the people of the developing economy, sometimes costs are higher than expected and revenues are not properly allocated. The initial investment in a tourism industry is very expensive and the burden often lies on the government, in turn using the revenue from tax payers. The tourism industry can create many jobs for a country; however, in some cases, tourism jobs may only be seasonal. The Myanmar case is an example of a country struggling to bring in visitors in during the rainy, low season, so the tourist industry depends on the high season. Additionally a country's tourism industry can easily be affected unexpected circumstances such as economic recessions, natural disasters, and terrorism. For example, although Jamaica has warm weather and may seem alluring for tourists all year round, they are faced with the hurricane season in the summer, during which time tourism is lower and many hotel chains even offer a free night stay on a guest's next visit if the weather is bad. As a destination becomes more attractive as a tourist destination and more people go to visit, the local community can be adversely affected and face an increase in local property prices and the cost of goods and services. Sometimes the money generated by tourism does not benefit the local community. Although the local community may generate a large revenue from tourism, portions of it often end up with large international corporations, such as hotel chains. [10] Additionally, tourism in flourishing tourist centers can cause price inflation, land speculation, and limit access to natural resources which lower income residents' livelihoods often depend upon. [11]

\section{Conclusion}

In conclusion, the paradox of tourism in countries with underdeveloped economies is a difficult hurtle for many to overcome. To grow a tourism industry, investment is necessary, but in a county with limited financial capital the growth opportunity is limited. To get a tourism industry started requires a large initial investment in infrastructure- a cost largely taken on by the government, but sometimes aided by outside investors. Establishing the basic infrastructure of safety and stability in addition to providing roads, airports, accommodation, and human capital is one of the greatest challenges to overcome. As shown in the Nigeria case, safety and stability is also a key factor that can restrict a country's tourism growth. Myanmar has developed its basic infrastructure, but is still overcoming the challenges of growth. And Jamaica is a country that established a solid tourism infrastructure which its economy now depends on, yet the country still struggles economically. There are positive and negative effects that a tourism industry can have on a developing economy. Overall it seems to have a positive impact on the countrywide economy, but in some cases can have a negative effect on individuals. Developing economies have a number of challenges to face in order to establish a tourism industry; however, if successful, the presence of tourism in a country has the potential to improve the economic situation. 


\section{References}

[1]. M. Honey, R. Gilpin. Tourism in the Developing World. United States Institute of Peace. October 19, 2009.

[2]. M. Honey, R. Gilpin. Tourism in the Developing World. United States Institute of Peace. October 19, 2009.

[3]. M. Honey, R. Gilpin. Tourism in the Developing World. United States Institute of Peace. October 19, 2009.

[4]. M. Honey, R. Gilpin. Tourism in the Developing World. United States Institute of Peace. October 19, 2009.

[5]. S. Black, Life and Debt, A Tuff Gong Pictures Production, 2001.

[6]. E.E. Thu, T. Kean. Why Myanmar's tourist numbers don't add up. Myanmar Times, January 19, 2015.

[7]. K. Kyaw. Myanmar looks to rebrand as a destination for foreign tourists. Eleven, January 15, 2017.

[8]. UNWTO. Tourism and Poverty Alleviation. The United Nations World Tourism Organization, 2012

[9]. C. Simm. Positive \& Negative Effects of Tourism. USA Today.

[10]. C. Simm. Positive \& Negative Effects of Tourism. USA Today.

[11]. EXO Foundation. The Paradox of Tourism. 